\title{
Study on the effect of EMD386088, a 5-HT 6 receptor partial agonist, in enhancing the anti-immobility action of some antidepressants in rats
}

\author{
Magdalena Jastrzębska-Więsek ${ }^{1}$ - Agata Siwek ${ }^{2}$ - Anna Partyka ${ }^{1}$. \\ Marcin Kolaczkowski ${ }^{3,4}$ - Maria Walczak ${ }^{5}$ - Magdalena Smolik ${ }^{5}$. Gniewomir Latacz ${ }^{6}$. \\ Katarzyna Kieć-Kononowicz ${ }^{6}$. Anna Wesolowska ${ }^{1}$
}

Received: 7 August 2017 / Accepted: 10 October 2017 /Published online: 27 October 2017

(C) The Author(s) 2017. This article is an open access publication

\begin{abstract}
The effect of some antidepressants co-administered with EMD386088 in the modified forced swim test in rats was investigated. Additionally, the pharmacokinetics, metabolic stability, and the effect of EMD386088 on P450 cytochromes were determined. Intraperitoneal (i.p.) coadministration of EMD386088 $(2.5 \mathrm{mg} / \mathrm{kg})$ and imipramine $(15 \mathrm{mg} / \mathrm{kg})$, reboxetine $(5 \mathrm{mg} / \mathrm{kg})$, moclobemide $(10 \mathrm{mg} / \mathrm{kg})$, or bupropion $(10 \mathrm{mg} / \mathrm{kg})$ evoked significant antidepressant-like activity, whereas no effect was observed after joint administration of EMD386088 with s-citalopram $(10 \mathrm{mg} / \mathrm{kg})$. Pharmacokinetic in vivo investigation showed a rapid absorption of EMD386088 $(2.5$ and $5 \mathrm{mg} / \mathrm{kg})$ with $t_{1 / 2}=67 \mathrm{~min}(t$ $\max =5 \mathrm{~min})$. Large volume of distribution $\left(V_{\mathrm{d}} / \mathrm{F}=102 \mathrm{~L} /\right.$ $\mathrm{kg}$ ) indicated its penetration into peripheral compartments. The most active coadministration of EMD386088 (2.5 mg/ $\mathrm{kg})$ with imipramine $(15 \mathrm{mg} / \mathrm{kg})$ resulted in slower absorption of the compound $\left(C_{\max }=60 \mathrm{~min}\right)$ and decrease in the volume of distribution $\left(V_{\mathrm{d}} / \mathrm{F}=32.2 \mathrm{~L} / \mathrm{kg}\right)$. EMD386088 penetrates the
\end{abstract}

Magdalena Jastrzębska-Więsek

m.jastrzebska-wiesek@uj.edu.pl

1 Department of Clinical Pharmacy, Jagiellonian University Medical College, 9 Medyczna Street, 30-688 Cracow, Poland

2 Department of Pharmacobiology, Jagiellonian University Medical College, 9 Medyczna Street, 30-688 Cracow, Poland

3 Department of Pharmaceutical Chemistry, Jagiellonian University Medical College, 9 Medyczna Street, 30-688 Cracow, Poland

4 Adamed Ltd., Pienków 149, 05-152 Czosnów, Poland

5 Department of Toxicology, Jagiellonian University Medical College, 9 Medyczna Street, 30-688 Cracow, Poland

6 Department of Technology and Biotechnology of Drugs, Jagiellonian University Medical College, 9 Medyczna Street,

30-688 Cracow, Poland blood-brain barrier with a high brain/plasma ratio of about 19 $(2.5 \mathrm{mg} / \mathrm{kg}$ ) and 7.5 for coadministration with imipramine. The in silico and in vitro studies on EMD386088 metabolic stability showed the dehydrogenation of tetrahydropyridine moiety as its main metabolic pathway. EMD386088 did not influence on CYP3A4 activity, and it has been classified as a very weak CYP2D6 inhibitor $\left(I C_{50}=2.25 \mu \mathrm{M}\right)$. The results obtained from the forced swim test in rats indicate that an activation of $5 \mathrm{HT}_{6}$ receptor may facilitate antidepressant-like activity of some antidepressants. The pharmacokinetic results suggest that the interaction between EMD386088 and imipramine could not have been pharmacokinetic in nature.

Keywords EMD386088 $\cdot 5-\mathrm{HT}_{6}$ receptor partial agonist . Antidepressants $\cdot$ Pharmacokinetic $\cdot$ Metabolic stability

\section{Introduction}

The serotonin-6 $\left(5-\mathrm{HT}_{6}\right)$ receptors belong to serotonin receptors that are positively coupled to the $\mathrm{G}_{\mathrm{s}}$ protein and stimulate adenylate cyclase activity (Monsma et al. 1993; Ruat et al. 1993; Plassat et al. 1993). Their distribution in the limbic areas and ability for different neurotransmission system modulations (i.e., cholinergic, glutamatergic, and $\gamma$-aminobutyric acid-ergic (GABAergic)) indicate that $5-\mathrm{HT}_{6}$ receptors are involved in mood and cognitive processes (Ward et al. 1995; Gérard et al. 1996; Yoshioka et al. 1998; Takamori et al. 2001). Literature preclinical data show that $5-\mathrm{HT}_{6}$ receptors have an important function in regulating mood since both agonists/partial agonists (i.e., WAY181187, WAY208466, EMDT, ST1936) and antagonists (i.e., SB271046, SB258585, SB399885) of these receptors possess antidepressant-like activity (Svenningsson et al. 2007; 
Wesołowska et al. 2007; Wesołowska 2008; Hirano et al. 2009; Carr et al. 2011; Nikiforuk et al. 2011; JastrzębskaWięsek et al. 2014, 2015). At present, it is difficult to indicate molecular mechanisms through which both activation and blockade of these receptors are able to evoke the same antidepressant effect observed in animals.

The compound EMD386088 has been presented by Mattsson et al. (2005) as a $5-\mathrm{HT}_{6}$ receptor agonist $\left(\mathrm{EC}_{50}=1.0 \mathrm{nM}\right)$. Recently obtained in vitro results demonstrated that EMD386088 behaves as a potent $5-\mathrm{HT}_{6}$ receptor partial agonist (Jastrzębska-Więsek et al. 2013). It also has no

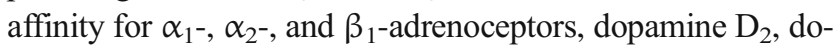
pamine $\mathrm{D}_{3}, \mathrm{GABA}_{\mathrm{A}}$, opioid $\mu$ receptors, and serotonin $(5-\mathrm{HT})$ transporter (Jastrzębska-Więsek et al. 2013). Previous findings have indicated that EMD386088 exerts an antidepressant-like effect after acute, sub-chronic (three times during $24 \mathrm{~h}$ in the forced swim test (FST)) and chronic (once daily for 14 days) systemic administration in the olfactory bulbectomy model in rats (Jastrzębska-Więsek et al. 2015). Previously obtained data confirm the importance of dopaminergic system activation in antidepressant-like activity of EMD386088 after acute administration, since this effect, observed in the FST, was abolished by the preferential $\mathrm{D}_{1^{-}}$and $\mathrm{D}_{2}$-like receptor subfamily antagonists $\mathrm{SCH} 23390$ and sulpiride, respectively (Jastrzębska-Więsek et al. 2016). In the ex vivo neurochemical studies, EMD386088 changed only the dopamine metabolism and activity of dopaminergic system in all investigated brain structures, i.e., hippocampus, nucleus accumbens, and striatum but there was not observed effect on the noradrenergic- or serotonergic system. In functional in vitro study, EMD386088 showed significant affinity for dopamine transporter (DAT). These all data confirm that antidepressant-like activity of EMD386088 in FST may be connected with the activation of dopaminergic system, while neither noradrenergic nor serotonergic ones are involved in its effect (Jastrzębska-Więsek et al. 2016).

We designed a modified version of FST in rats to evaluate the interaction between EMD386088 and some antidepressants with a different mechanism of action. Antidepressant drugs, chosen for the study, included the 5-HT/noradrenaline reuptake inhibitor imipramine, the selective noradrenaline reuptake inhibitor reboxetine, the selective 5-HT reuptake inhibitor s-citalopram, the dopamine reuptake inhibitor bupropion, and the monoamine oxidase-A inhibitor moclobemide. All compounds were given as non-active doses, chosen from the results of our earlier studies (Wesołowska and Nikiforuk 2007; Jastrzębska-Więsek et al. 2015).

Since pharmacokinetic studies are an important part of tests performed for new compounds with proven biological activity, we decided to investigate the pharmacokinetic profile of EMD386088 through a single i.p. administration and by coadministration with imipramine. We also chose to determine in vitro, the effect of EMD386088 on recombinant isoenzymes CYP3A4 and CYP2D6 of P450 cytochrome, since their potential inhibition could be involved in antidepressant effects observed in FST. Metabolic stability of EMD386088 was also evaluated in silico by MetaSite software and in vitro using rat liver microsomes (RLMs).

\section{Material and methods}

\section{Animals}

The experiments were performed on male Wistar rats (250$300 \mathrm{~g})$ purchased from Charles River Laboratories (Germany). The animals were housed for a period of 6 days in polycarbonate Makrolon type 3 cages (dimensions $26.5 \times 15 \times 42 \mathrm{~cm}$ ) in an environmentally controlled room (ambient temperature $21 \pm 2{ }^{\circ} \mathrm{C}$; relative humidity 50-60\%; 12:12 light:dark cycle, lights on at 8:00), in groups of four rats. Standard laboratory food (LSM-B) and filtered water were freely available.

In behavioral experiments, animals were assigned randomly to treatment groups. All the tests were performed by two observers unaware of the treatment applied between 9:00 and 14:00 on separate groups of animals.

A pharmacokinetic study was carried out for EMD386088 and imipramine following their single and combined i.p. administrations to rats. Blood samples were collected at $0 \mathrm{~min}$ (predose), $5 \mathrm{~min}, 15 \mathrm{~min}, 30 \mathrm{~min}, 60 \mathrm{~min}, 120 \mathrm{~min}$, and $240 \mathrm{~min}$ after injections. The blood was collected from right ventricle under anesthesia using a mixture of ketamine $(50 \mathrm{mg} / \mathrm{kg}) / \mathrm{xylasine}(8 \mathrm{mg} / \mathrm{kg})$ in the ratio of $3: 1$, and $0.025 \mathrm{~mL}$ of a mixture for $10 \mathrm{~g}$ body weight was injected i.p. $10 \mathrm{~min}$ before planned blood collection. Blood and brain samples were collected under general anesthesia induced by i.p. injections of ketamine $(50 \mathrm{mg} / \mathrm{kg}) /$ xylasine $(8 \mathrm{mg} / \mathrm{kg})$. The blood samples were taken into heparinized tubes, immediately centrifuged at $3500 \mathrm{rpm}$ for $10 \mathrm{~min}$, and plasma was collected. After the blood was drawn, the rat's spinal cord was cut and the cerebral tissue was removed, and after dissection washed in PBS saline. The brain and plasma samples were immediately frozen at $-80{ }^{\circ} \mathrm{C}$ for LC/MS/MS analysis.

Procedures involving animals and their care were conducted in accordance with current European Community and Polish legislation on animal experimentation. Additionally, all efforts were made to minimize animal suffering and to use only the number of animals necessary to produce reliable scientific data. The experimental protocols and procedures described in this manuscript were approved by the IV Local Ethics Commission in Warsaw (no 40/2008) and were in accordance with EU Directive 2010/63/EU and the 1996 NIH Guide for the Care and Use of Laboratory Animals. 


\section{Drugs}

The following drugs were used: 5-chloro-2-methyl-3-(1,2,3,6tetrahydro-4-pyridinyl)- $1 H$-indole hydrochloride (EMD386088) and s-citalopram were synthesized by Adamed (Pieńków, Poland), imipramine (Sigma Aldrich, Germany), moclobemide (Sigma Aldrich, Germany), reboxetine (Ascent, UK), bupropion (Sigma Aldrich, Germany), xylazine (Sigma-Aldrich, USA), ketamine (Vetoquinol, Poland). All drugs were dissolved in distilled water immediately before administration in a volume of $2 \mathrm{~mL} / \mathrm{kg}$. All the compounds were administered intraperitoneally (i.p.). EMD386088, imipramine, and s-citalopram were given $30 \mathrm{~min}$ before the test, while the remaining compounds were injected $60 \mathrm{~min}$ before. Control animals received vehicle according to the same schedule.

\section{Behavioral experiments}

\section{Forced swim test in rats}

The experiment was carried out according to the modified by Detke et al. (1995) method of Porsolt et al. (1978). On the first day of an experiment, the animals were gently individually placed in Plexiglas cylinders (40 $\mathrm{cm}$ high, $18 \mathrm{~cm}$ in diameter) containing $30 \mathrm{~cm}$ of water maintained at $23-25^{\circ} \mathrm{C}$ for $15 \mathrm{~min}$. On removal from water, the rats were placed for $30 \mathrm{~min}$ in a Plexiglas box under $60-\mathrm{W}$ bulb to dry. On the following day ( $24 \mathrm{~h}$ later), the rats were re-placed in the cylinder and the total duration of immobility, swimming, and climbing was recorded during the whole 5-min test period. The swimming behavior entailed active swimming motions, e.g., moving horizontally around in the cylinder. Climbing activity consisted of upward directed movements of the forepaws along the side of the swim chamber, and immobility was assigned when no additional activity was observed other than that necessary to keep the rat's head above the water (Detke et al. 1995). Fresh water was used for each animal.

\section{Open field test in rats}

The experiment was performed using Motor Monitor System (Campden Instruments, Ltd., UK) consisted of two SmartFrame Open Field stations $(40 \times 40 \times 38 \mathrm{~cm})$ with $16 \times 16$ beams, located in sound attenuating chambers and connected to PC software by control chassis. Individual vehicle- or drug-injected animals were gently placed in the center of the station. An automated motor monitor system recorded ambulation (the number of crossings in $\mathrm{X}$ and $\mathrm{Y}$ axis), the number of rearing episodes, and total distance covered by a rat for $5 \mathrm{~min}$.

\section{Statistical analysis}

The data of behavioral studies were evaluated using two-way analysis of variance (ANOVA) followed by Bonferroni's post hoc test, $p<0.05$ was considered significant.

\section{Pharmacokinetic study in rats}

Pharmacokinetic parameters were calculated by a noncompartmental approach from the average concentration values, using Phoenix WinNonlin software (Certara, Princeton, NJ 08540 USA). First order elimination rate constant $\left(\lambda_{\mathrm{z}}\right)$ was calculated by linear regression of time versus log concentration. Next, the area under the mean plasma and brain concentration versus time curve $\left(\mathrm{AUC}_{0} \rightarrow \mathrm{t}\right)$ was estimated using the log-linear trapezoidal rule (Eq. 1), where $C_{\mathrm{n}}$ is the concentration of last sampling of the compound.

$$
\mathrm{AUC}_{0 \rightarrow \mathrm{t}}=\sum_{i=1}^{n}\left(\left(C_{i}+C_{i+1}\right) / 2\right) \cdot\left(t_{i+1}-t_{i}\right)+C_{\mathrm{n}} / \lambda_{\mathrm{z}}
$$

Area under the first-moment curve $\left(\mathrm{AUMC}_{0 \rightarrow \mathrm{t}}\right)$ was estimated by calculation of the total area under the firstmoment curve using the Eq. 2, where $t_{\mathrm{n}}$ is the time of last sampling.

$$
\begin{aligned}
A U M C_{0 \rightarrow \mathrm{t}}= & \sum_{\mathrm{i}=1}^{n}\left(\left(t_{i} \cdot C_{i}+t_{i+1} \cdot C_{i+1}\right) / 2\right) \cdot\left(t_{i+1}-t_{i}\right) \\
& +\left(t_{\mathrm{n}} \cdot C_{\mathrm{n}}\right) / \lambda_{\mathrm{z}}+C_{\mathrm{n}} / \lambda_{\mathrm{z}}^{2}
\end{aligned}
$$

Mean residence time (MRT) was calculated as follows:

$\mathrm{MRT}=\frac{A U M C_{0 \rightarrow t}}{\mathrm{AUC}_{0 \rightarrow t}}$

Total clearance $\left(\mathrm{Cl}_{\mathrm{T}}\right)$ was calculated as follows:

$\mathrm{Cl}_{\mathrm{T}}=\frac{F \cdot D_{\text {i.p. }}}{\mathrm{AUC}_{0 \rightarrow t}}$

Volume of distribution $\left(V_{\mathrm{d}}\right)$ was calculated as:

$V_{\mathrm{d}}=\frac{F \cdot D_{\text {i.p. }}}{\lambda_{\mathrm{z}} \cdot \mathrm{AUC}_{0 \rightarrow t}}$

where $D_{\text {i.p. }}$ is an i.p. dose of EMD386088.

\section{Analytical method}

The quantification of studied compounds in plasma and brain samples was done using HPLC Agilent 1100 system (Agilent Technologies, Waldbronn, Germany) coupled to the triple quadrupole mass spectrometer API 2000 (ABSciex, Framingham, Massachusetts, USA) equipped with an electrospray ion source. After preparation, the 
samples were injected $(20 \mu \mathrm{L})$ onto XBridge $\mathrm{C}_{18}$ $(2.1 \mathrm{~mm} \times 30 \mathrm{~mm}, 3.5 \mu \mathrm{m}$, Waters, Milford, Massachusetts, USA) analytical column. The mobile phase consisted of ACN with $0.1 \%$ formic acid (A) and water with $0.1 \%$ formic acid (B) were delivered in gradient elution started with $90 \%$ of eluent B, increasing during 2 min to $90 \%$ of eluent $\mathrm{A}$, maintained to $3 \mathrm{~min}$, and then returned during $5 \mathrm{~min}$ to $90 \%$ of eluent $\mathrm{B}$, and maintained $90 \%$ of eluent $\mathrm{B}$ during $5 \mathrm{~min}$ at a flow rate of $300 \mu \mathrm{L} / \mathrm{min}$. The total time of analysis was $15 \mathrm{~min}$. Electrospray ionization process was performed in positive ionization and the data acquisition was carried out in multiple reaction monitoring mode (MRM) for EMD386088 and its internal standard (nebivolol). The ion spray source settings were as follows: spray voltage: $5 \mathrm{kV}$, heater temperature: $350^{\circ} \mathrm{C}$, curtain gas: $15 \mathrm{psi}$, source gas $1: 35 \mathrm{psi}$, source gas 2: $10 \mathrm{psi}$. The ions measured were $\mathrm{m} / \mathrm{z} 247.3$ (Q1) and m/z 168.2 (Q3) for EMD386088, and m/z 406.2 (Q1) and m/z 151.1 (Q3) for IS.

\section{Preparation of standard solutions}

An amount of $10 \mathrm{mg}$ of EMD386088 was accurately weighted and quantitatively transferred into the $10-\mathrm{mL}$ volumetric flask using $\mathrm{MeOH}$. After the salts dissolving, flask was filled to the $10-\mathrm{mL}$ mark with $\mathrm{MeOH}$ obtaining $1 \mathrm{mg} / \mathrm{mL}$ of an analyte. Further dilutions were performed using $\mathrm{MeOH}$ to prepare working standard solutions of the analyte at the following concentrations: $0.025,0.05,0.1,0.25,0.5,1.0,2.5,5.0,10$, 25 , and $50 \mu \mathrm{g} / \mathrm{mL}$ for calibration curve samples (CC) and $0.025,0.075,2.2$, and $4.5 \mu \mathrm{g} / \mathrm{mL}$ for quality control samples (QC). To prepare samples for calibration curve or quality control samples, $45 \mu \mathrm{L}$ of matrix (plasma or brain homogenate) were spiked with $5 \mu \mathrm{L}$ of an internal standard solution obtaining the final concentration of $100 \mathrm{ng} / \mathrm{mL}$ and $5 \mu \mathrm{L}$ of standards working solutions at needed CC or QC concentration levels. After standards solution addition, samples were mixed and purified.

\section{Sample preparation}

A sample volume of $50 \mu \mathrm{L}$ of plasma or brain homogenate was transferred into the clean Eppendorf tube and spiked with $5 \mu \mathrm{L}$ of IS solution $(1 \mu \mathrm{g} / \mathrm{mL})$ obtaining the final concentration of $100 \mathrm{ng} / \mathrm{mL}$. After 5 min of mixing $(1500 \mathrm{rpm})$, proteins were precipitated using $150 \mu \mathrm{L}$ ACN. After $10 \mathrm{~min}$ of samples shaking $(1500 \mathrm{rpm})$, the incubation step was performed $\left(10 \mathrm{~min}, 4^{\circ} \mathrm{C}\right)$. Next, samples were centrifuged $\left(10,000 \mathrm{rpm}, 10 \mathrm{~min}, 4{ }^{\circ} \mathrm{C}\right)$ and the supernatant was transferred into chromatographic vial for LC/MS/MS analysis. The brain homogenate was prepared maintaining the tissue: phosphate-buffered saline (PBS) at a ratio of 1:5. The homogenization was carried out employing IKA® T10 Basic ULTRA-TURRAX disperser (IKA Werke GmbH \& Co. KG, Staufen, Germany). After homogenization, $50 \mu \mathrm{L}$ of sample was collected for further preparation. All samples were stored on ice during the preparation process.

\section{Metabolic stability of EMD386088 investigations}

\section{In silico investigation}

The in silico study was performed by MetaSite 5.1.1 provided by Molecular Discovery Ltd. The highest metabolism probability sites and the prediction of the structures of metabolites were analyzed during this study by liver computational model (Cruciani et al. 2005).

\section{In vitro investigation}

Commercial, pooled, rat liver microsomes (RLMs) were purchased from Sigma-Aldrich (St. Louis, USA). The biotransformations were carried out using $1 \mathrm{mg} / \mathrm{mL}$ of RLMs in $200 \mu \mathrm{L}$ of reaction buffer containing $0.1 \mathrm{M}$ Tris- $\mathrm{HCl}$ (pH 7.4) and EMD386088 with final volume $50 \mu \mathrm{M}$. The reaction mixture was preincubated at $37^{\circ} \mathrm{C}$ for $5 \mathrm{~min}$ and then, the reaction was initiated by adding $50 \mu \mathrm{L}$ of NADPH Regeneration System (Promega, Madison, WI, USA). The reaction was terminated after 30 or $120 \mathrm{~min}$ by the addition of $200 \mu \mathrm{L}$ of cold methanol. The mixture was next centrifuged at $14000 \mathrm{rpm}$ for $15 \mathrm{~min}$ and the UPLC/MS analysis of the supernatant was performed. Mass spectra was recorded on UPLC/MS system consisted of a Waters Acquity UPLC (Waters, Milford, USA), coupled to a Waters TQD mass spectrometer (electrospray ionization mode ESI-tandem quadrupole).

\section{Influence on recombinant human CYP3A4 and 2D6 P450 cytochromes}

The luminescent CYP3A4 P450-Glo ${ }^{\mathrm{TM}}$ and CYP2D6 P450$\mathrm{Glo}^{\mathrm{TM}}$ assays and protocols were provided by Promega (Madison, WI, USA) (Cali et al. 2006). The reference drugs ketoconazole (KE) and quinidine (QD) were obtained from Sigma-Aldrich (St. Louis, USA). The enzymatic reactions were performed in white polystyrene, flat-bottom Nunc ${ }^{\mathrm{TM}}$ MicroWell ${ }^{\mathrm{TM}}$ 96-Well Microplates (Thermo Scientific, Waltham, MA USA). The luminescence signal was measured with a microplate reader in luminescence mode (EnSpire, PerkinElmer, Waltham, MA USA). The $\mathrm{IC}_{50}$ values of $\mathrm{KE}$ and QD were determined and calculated as we described previously (Sadek et al. 2016). The final concentrations of EMD 386088 were similar for both CYP3A4 and CYP2D6 assays from 0.025 to $25 \mu \mathrm{M}$. 


\section{Results}

\section{Interaction between EMD386088 and antidepressant drugs in the FST}

The results presented in Fig. 1 show that a concomitant administration of non-active doses of EMD386088 $(2.5 \mathrm{mg} / \mathrm{kg})$ and imipramine $(15 \mathrm{mg} / \mathrm{kg})$ showed in two-way ANOVA analysis of variance significant decreasing of immobility time $(\mathrm{F}(1,24)=23.628, p<0.0001)$ as well as increasing of climbing behavior $(\mathrm{F}(1,24)=12.444, p<0.01)$ respectively to the vehicle control and single administration of EMD386088 or imipramine (Fig. 1a). EMD386088 $(2.5 \mathrm{mg} / \mathrm{kg})$ co-administered with the non-active doses of reboxetine $(5 \mathrm{mg} / \mathrm{kg}$, Fig. 1b, $(\mathrm{F}(1,25)=6.5843, p<0.05))$, moclobemide $(10 \mathrm{mg} / \mathrm{kg}$, Fig. $1 \mathrm{c},(\mathrm{F}(1,25)=4.8193$, $\mathrm{p}<0.05)$ ) or bupropion $(10 \mathrm{mg} / \mathrm{kg}$, Fig. 1d, $(\mathrm{F}(1,26)=6.0071, \mathrm{p}<0.05))$ provoked statistically significant interactions only in an anti-immobility effect. A combination of non-active doses of EMD386088 $(2.5 \mathrm{mg} / \mathrm{kg})$ and scitalopram $(10 \mathrm{mg} / \mathrm{kg})$ did not produce any significant effect on immobility time, climbing behavior and swimming time in the FST (Fig. 1e, $(\mathrm{F}(1,24)=1.9267, \mathrm{NS})$.

\section{Effects of EMD386088 and the antidepressant drugs administered alone or jointly in the $\mathrm{OF}$ test}

The compound EMD386088 $(2.5 \mathrm{mg} / \mathrm{kg})$ co-administered with imipramine $(15 \mathrm{mg} / \mathrm{kg})$ significantly reduced total distance only evaluated by the OF test, whereas the other parameters, i.e., rearings, $\mathrm{X}$ and $\mathrm{Y}$ ambulation remained unchanged (Table 1). Other antidepressants given jointly with EMD386088 did not change animals' locomotor activity in that test. Antidepressants and EMD386088 administered alone had no effect on the exploratory activity in the OF test, except of s-citalopram $(10 \mathrm{mg} / \mathrm{kg})$ that significantly reduced total distance (Table 1).

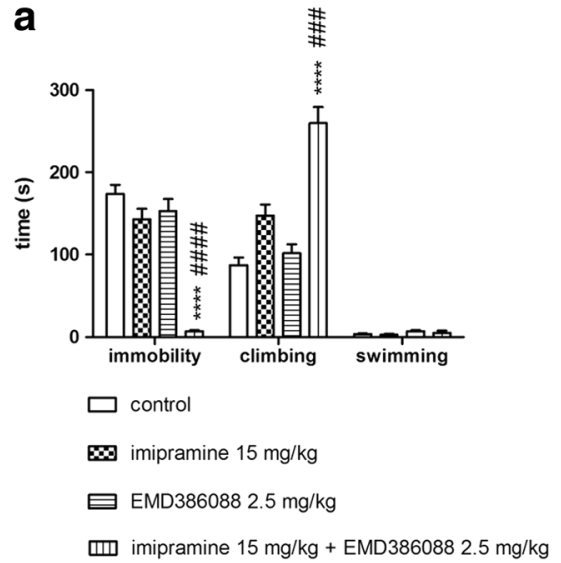

d

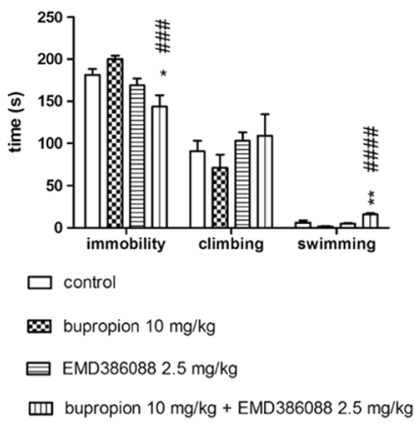

Fig. 1 Effects of EMD386088 and antidepressants given alone or in combination in the modified FST in rats. a Effects of EMD386088 and imipramine in the FST. b Effects of EMD386088 and reboxetine in the FST. $\mathbf{c}$ Effects of EMD386088 and moclobemide in the FST. d Effects of EMD386088 and bupropion in the FST. e Effects of EMD386088 and scitalopram in the FST. EMD386088, imipramine, and s-citalopram were injected i.p. $30 \mathrm{~min}$, while reboxetine, moclobemide, and bupropion were

\section{C}

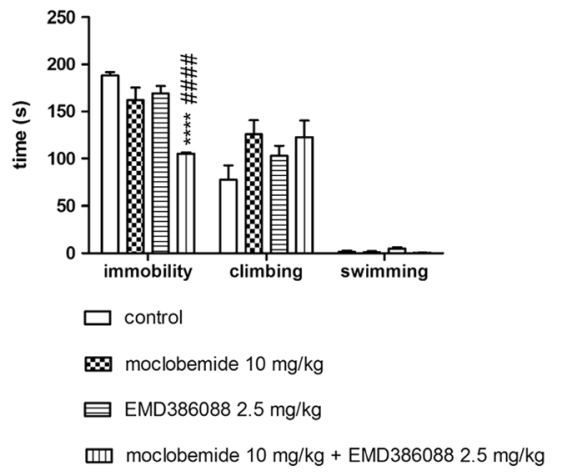

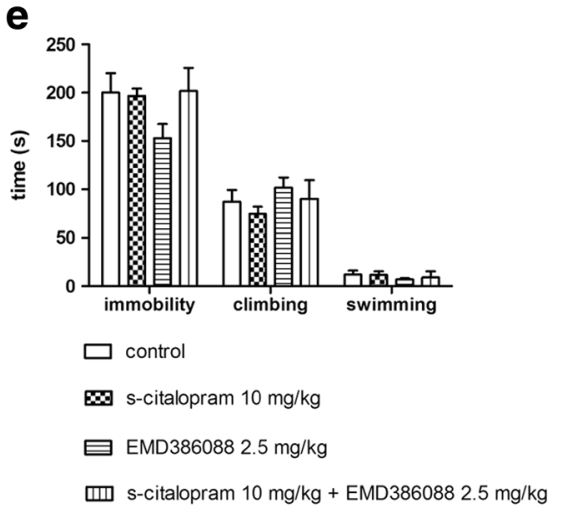

given i.p. $60 \mathrm{~min}$ before the test. Values represent the mean $\pm \mathrm{SEM}$ and were analyzed by two-way ANOVA followed by Bonferroni's post hoc test: $* p<0,05, * * p<0.01, * * * p<0.001$ relative to respective vehicle

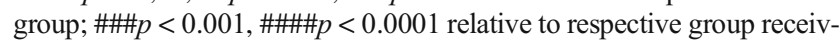
ing non-active dose of respective antidepressant drug without EMD386088, $N=6-8$ 
Table 1 Effect of EMD386088, imipramine, s-citalopram, reboxetine, moclobemide, and bupropion given alone or in combination on the rat locomotor activity measured in the OF test

\begin{tabular}{|c|c|c|c|c|c|}
\hline \multirow[t]{2}{*}{ Treatment } & \multirow{2}{*}{$\begin{array}{l}\text { Dose }(\mathrm{mg} / \\
\mathrm{kg})\end{array}$} & \multicolumn{4}{|l|}{ Exploratory activity } \\
\hline & & Total distance $(\mathrm{cm})$ & Rearings & Ambulation X & Ambulation Y \\
\hline Vehicle + Vehicle & $0+0$ & $2790 \pm 174$ & $72 \pm 10$ & $291 \pm 40$ & $275 \pm 30$ \\
\hline Vehicle + imipramine & $0+15$ & $2212 \pm 332$ & $54 \pm 3$ & $209 \pm 37$ & $203 \pm 41$ \\
\hline Vehicle + EMD 386088 & $0+2.5$ & $2677 \pm 232$ & $90 \pm 3$ & $261 \pm 29$ & $261 \pm 31$ \\
\hline $\begin{array}{l}\text { imipramine + EMD } \\
\quad 386088\end{array}$ & $15+5$ & $\begin{array}{l}1909 \pm 125 * \\
\mathrm{~F}(1,20)=0.4677 \\
\quad p=0.502\end{array}$ & $\begin{array}{l}89 \pm 9 \\
\mathrm{~F}(1,20)=1.0969 \\
\quad p=0.307\end{array}$ & $\begin{array}{l}165 \pm 25 \\
\mathrm{~F}(1,20)=0.0383 \\
\quad p=0.847\end{array}$ & $\begin{array}{l}157 \pm 30 \\
\mathrm{~F}(1,20)=0.2249 \\
\quad p=0.640\end{array}$ \\
\hline Vehicle + Vehicle & $0+0$ & $2790 \pm 174$ & $72 \pm 10$ & $291 \pm 40$ & $275 \pm 30$ \\
\hline Vehicle + s-citalopram & $0+10$ & $1935 \pm 121 *$ & $64 \pm 12$ & $197 \pm 15$ & $179 \pm 19$ \\
\hline Vehicle + EMD 386088 + & $0+2.5$ & $2677 \pm 232$ & $90 \pm 3$ & $261 \pm 29$ & $261 \pm 31$ \\
\hline $\begin{array}{l}\text { s-citalopram + EMD } \\
\quad 386088\end{array}$ & $10+2.5$ & $\begin{array}{l}2160 \pm 173 \\
\mathrm{~F}(1,20)=0.8898 \\
\quad p=0.357\end{array}$ & $\begin{array}{l}69 \pm 8 \\
\mathrm{~F}(1,20)=0.5108 \\
\quad p=0.483\end{array}$ & $\begin{array}{l}228 \pm 26 \\
\mathrm{~F}(1,20)=1.1364 \\
\quad p=0.299\end{array}$ & $\begin{array}{l}232 \pm 27 \\
\mathrm{~F}(1,20)=1.5337 \\
\quad p=0.230\end{array}$ \\
\hline Vehicle + Vehicle & $0+0$ & $3102 \pm 434$ & $94 \pm 13$ & $274 \pm 40$ & $281 \pm 38$ \\
\hline Vehicle + reboxetine & $0+5$ & $2196 \pm 74$ & $84 \pm 6$ & $221 \pm 16$ & $220 \pm 12$ \\
\hline Vehicle + EMD 386088 + & $0+2.5$ & $2721 \pm 196$ & $91 \pm 4$ & $262 \pm 28$ & $261 \pm 31$ \\
\hline reboxetine + EMD 386088 & $5+2.5$ & $\begin{array}{l}2651 \pm 265 \\
\mathrm{~F}(1,20)=1.8780 \\
\quad p=0.186\end{array}$ & $\begin{array}{l}87 \pm 6 \\
\mathrm{~F}(1,20)=0.0431 \\
\quad p=0.838\end{array}$ & $\begin{array}{l}267 \pm 37 \\
\mathrm{~F}(1,20)=0.8117 \\
\quad p=0.378\end{array}$ & $\begin{array}{l}269 \pm 34 \\
\mathrm{~F}(1,20)=1.6607 \\
\quad p=0.212\end{array}$ \\
\hline Vehicle + Vehicle & $0+0$ & $3102 \pm 434$ & $94 \pm 13$ & $274 \pm 40$ & $281 \pm 38$ \\
\hline Vehicle + moclobemide & $0+10$ & $2160 \pm 183$ & $62 \pm 3$ & $200 \pm 26$ & $192 \pm 23$ \\
\hline Vehicle + EMD 386088 + & $0+2.5$ & $2644 \pm 220$ & $89 \pm 4$ & $262 \pm 35$ & $267 \pm 37$ \\
\hline $\begin{array}{l}\text { moclobemide + EMD } \\
386088\end{array}$ & $10+2.5$ & $\begin{array}{l}2405 \pm 168 \\
\mathrm{~F}(1,19)=1.5830 \\
\quad p=0.223\end{array}$ & $\begin{array}{l}69 \pm 6 \\
\mathrm{~F}(1,19)=0.5090 \\
\quad p=0.484\end{array}$ & $\begin{array}{l}229 \pm 25 \\
\mathrm{~F}(1,19)=0.4146 \\
\quad p=0.527\end{array}$ & $\begin{array}{l}244 \pm 30 \\
\mathrm{~F}(1,19)=1.0302 \\
\quad p=0.322\end{array}$ \\
\hline Vehicle + Vehicle & $0+0$ & $2696 \pm 308$ & $71 \pm 7$ & $251 \pm 31$ & $270 \pm 40$ \\
\hline Vehicle + bupropion & $0+10$ & $3083 \pm 229$ & $83 \pm 9$ & $284 \pm 31$ & $301 \pm 35$ \\
\hline Vehicle + EMD 386088 + & $0+2.5$ & $2722 \pm 145$ & $92 \pm 9$ & $263 \pm 28$ & $262 \pm 23$ \\
\hline $\begin{array}{l}\text { Bupropion + EMD } \\
386088\end{array}$ & $10+2.5$ & $\begin{array}{l}3284 \pm 306 \\
\mathrm{~F}(1,20)=0.1094 \\
\quad p=0.744\end{array}$ & $\begin{array}{l}85 \pm 6 \\
\mathrm{~F}(1,20)=2.0155 \\
\quad p=0.171\end{array}$ & $\begin{array}{l}365 \pm 47 \\
\mathrm{~F}(1,20)=0.9526 \\
\quad p=0.341\end{array}$ & $\begin{array}{l}334 \pm 30 \\
\mathrm{~F}(1,20)=0.3473 \\
\quad p=0.562\end{array}$ \\
\hline
\end{tabular}

EMD386088, imipramine, and s-citalopram were injected i.p. $30 \mathrm{~min}$, while reboxetine, moclobemide and bupropion were given i.p. 60 min before the test. Values represent the mean \pm SEM during 5-min test session compared to the respective group: vehicle + vehicle group * $p<0.05$, NS not significant (two-way ANOVA is followed by the Bonferroni's post hoc test), $N=6$

\section{Pharmacokinetic study}

The plots of mean plasma and brain concentrations versus time profile for EMD386088 administered alone at doses of 2.5 and $5 \mathrm{mg} / \mathrm{kg}$ and jointly $2.5 \mathrm{mg} / \mathrm{kg}$ with imipramine $(15 \mathrm{mg} / \mathrm{kg})$ are depicted in Fig. 2.

The pharmacokinetic parameters for EMD386088 calculated by non-compartmental approach are given in Table 2 . The compound was eliminated relatively quickly from rats' body and its terminal half-life time was about $70 \mathrm{~min}$. EMD386088 showed a large volume of distribution $(102 \mathrm{~L} / \mathrm{kg}$ ) that indicates its ability for penetration to the deep compartment. EMD386088 reached the maximum concentration in the blood within $5 \mathrm{~min}$. Coadministration of the compound with imipramine increased the time to reach the maximum concentration $\left(t_{\max }=60 \mathrm{~min}\right)$, increased three times the area under the concentration-time curve (AUC), and decreased three times its volume of distribution. The investigated compound exhibited significant distribution to brain which is in agreement with its high volume of distribution but exposition of EMD386088 in the brain after i.p. administration is slow $\left(t_{\max }=120 \mathrm{~min}\right)($ Table 2$)$. The brain to plasma ratio calculated on the basis of $\mathrm{AUC}_{0} \rightarrow \mathrm{t}$ values is very high, ca. 19 . Coadministration of EMD386088 with imipramine decreased about two times the brain/plasma ratio (Table 3).

\section{Metabolic stability of EMD386088 study}

The metabolic stability of EMD386088 was examined first in silico by using MetaSite software (Cruciani et al. 2005). The plot of MetSite predictions for the most probable sites of 

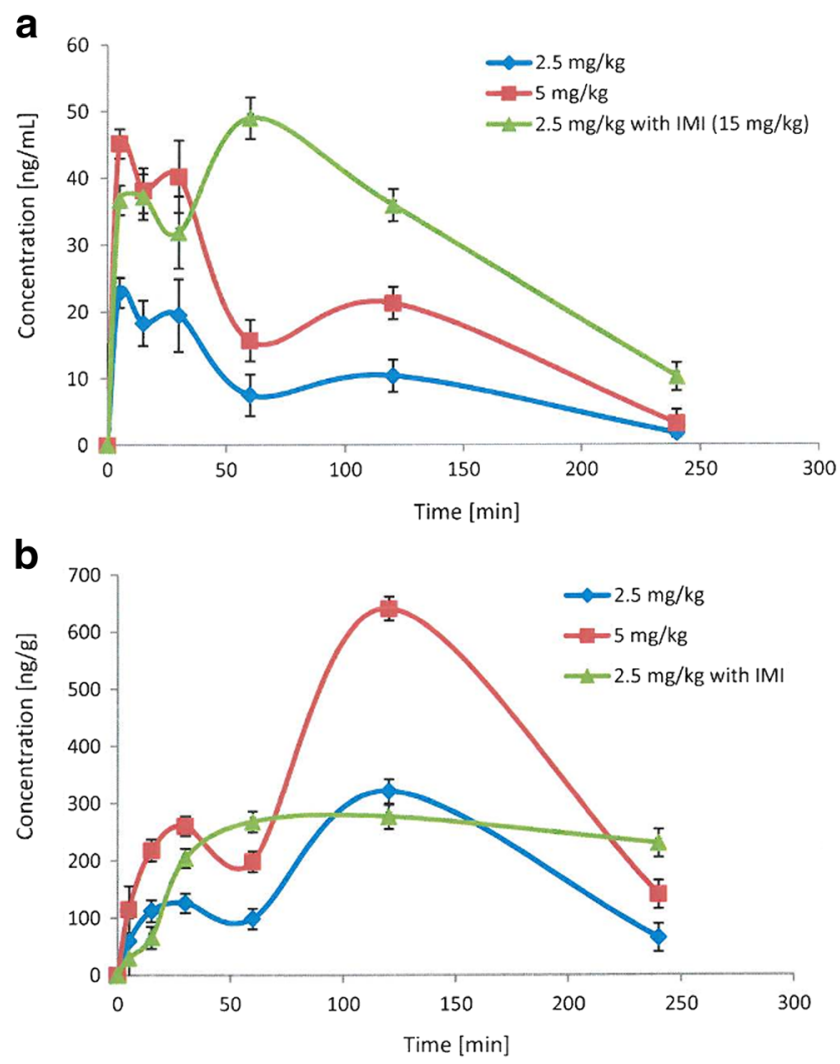

Fig. 2 Concentration-time profile of EMD386088 in plasma (a) and the brain (b) administered alone or jointly with imipramine (IMI) in rats

metabolism of EMD386088 by liver computational model is shown in Fig. 3.

The darker gray color of the marked functional group indicates its higher probability to be involved in the metabolism pathway. The black circle marked the site of EMD386088 involved in metabolism with the highest probability.

MetaSite is also able to predict the most probably structures of metabolites. The metabolites ranking and the structures of 10 metabolites which may occur with the highest probability $(>50 \%)$ are presented on Figs. 4 and 5.

The metabolic stability of EMD386088 was also evaluated in vitro using RLMs. A full scan chromatogram of the reaction mixture after 30 min of EMD386088 incubation showed the presence of one metabolite M-I, whereas after $120 \mathrm{~min}$ its four metabolites (M I-IV) occurred (Figs. 6 and 7). Moreover, as was shown at the UPLC spectrum (Fig. 6), EMD386088 seems to be rather a metabolically unstable molecule, because almost $40 \%$ of the compound was metabolized in the presence of RLMs after 120 min.

The LC/MS analysis provided the accurate molecular masses of all EMD386088 metabolites which were up from $\mathrm{m} / \mathrm{z}=247.26$ to $\mathrm{m} / \mathrm{z}=261.22$ corresponding to the quasimolecular ions $[\mathrm{M}+\mathrm{H}]^{+}$of metabolites M-III and MIV or down to $\mathrm{m} / \mathrm{z}=245.27$ (M-I) or $\mathrm{m} / \mathrm{z}=243.21$ (M-II) (Fig. 7).

The most probable structural formulas of metabolites proposed by MetaSite program were compared with the masses of pseudomolecular ions from LC/MS analysis. Regarding obtained by RLMs, the main EMD386088 metabolite M-I, its molecular mass corresponds to the proposed structure of M5 (Fig. 4) obtained by the dehydrogenation of tetrahydropyridine moiety. The molecular mass of metabolite M-II was not found in in silico data, however, this metabolite seems to be the effect of succeeding dehydrogenation of metabolite M-I (Fig. 8).

The molecular masses of metabolites M-III and M-IV correspond to the predicted in silico structures of $M 1, M 6$, and M10 (Fig. 4) which are the effect of EMD386088 oxygenation either in the methyl substituent or in the tetrahydropyridine moiety.

\section{Effect of EMD386088 on CYP3A4 and CYP2D6 activity}

The additional study was performed to determine the effect of EMD386088 on CYP3A4 and 2D6 activity. The strong CYP3A4 inhibitor ketoconazole $\left(\mathrm{KE} I C_{50}=0.1 \mu \mathrm{M}\right)$, and strong CYP2D6 inhibitor quinidine $\left(\mathrm{QD} I C_{50}=0.01 \mu \mathrm{M}\right)$

Table 2 Pharmacokinetic parameters for EMD386088 administered alone or jointly with imipramine (IMI) in rats

\begin{tabular}{lccc}
\hline Parameters & \multicolumn{2}{l}{ Dose $[\mathrm{mg} / \mathrm{kg}]$} & \\
\cline { 2 - 4 } & EMD386088 2.5 & EMD386088 5 & EMD386088 2.5 + IMI 15 \\
\hline $\mathrm{AUC}_{0} \rightarrow \mathrm{t}[\mathrm{ng} \cdot \mathrm{min} / \mathrm{mL}]$ & 2210.6 & 4527.4 & 7505.5 \\
$\mathrm{t}_{1 / 2}[\mathrm{~min}]$ & 67.3 & 64.9 & 77.1 \\
$\mathrm{MRT}[\mathrm{min}]$ & 78.7 & 78 & 92.8 \\
$C_{\max }[\mathrm{ng} / \mathrm{mL}]$ & 22.9 & 45.2 & 49 \\
$t_{\max }[\mathrm{min}]$ & 5 & 5 & 60 \\
$V_{\mathrm{d}} / \mathrm{F}[\mathrm{mL} / \mathrm{kg}]$ & $102,183.9$ & $97,140.3$ & $32,204.7$ \\
$\mathrm{Cl} / \mathrm{F}[\mathrm{mL} / \mathrm{min} / \mathrm{kg}]$ & 1052.6 & 1038.8 & 289.4 \\
\hline
\end{tabular}

EMD386088 and imipramine were injected i.p.

$A U C$ area under the curve, $t_{0.5}$ terminal half-life, $C_{\max }$ maximum plasma concentration, $t_{\max }$ time to $C_{\max }, V_{d} / F$ apparent volume of distribution, $C l / F$ apparent systemic clearance, $M R T$ mean residence time 
Table 3 Distribution of EMD386088 administered alone or jointly with imipramine (IMI) in rats' brain

\begin{tabular}{lccc}
\hline Parameters & \multicolumn{2}{l}{ Dose $[\mathrm{mg} / \mathrm{kg}]$} & \\
\cline { 2 - 4 } & EMD386088 2.5 & EMD386088 5 & EMD38688 2.5 + IMI 15 \\
\hline $\mathrm{AUC}_{0 \rightarrow \mathrm{t}}[\mathrm{ng} \cdot \mathrm{min} / \mathrm{g}]$ & $41,936.2$ & $84,462.8$ & $56,428.6$ \\
$\mathrm{MRT}[\mathrm{min}]$ & 114 & 114.8 & 127.2 \\
$C_{\max }[\mathrm{ng} / \mathrm{g}]$ & 321 & 640.3 & 276.9 \\
$t_{\max }[\mathrm{min}]$ & 120 & 120 & 120 \\
\hline
\end{tabular}

EMD386088 and imipramine were injected i.p.

$A U C$ area under the curve; $M R T$ mean residence time; $C_{\max }$ maximum plasma concentration; $t_{\max }$ time to $C_{\max }$

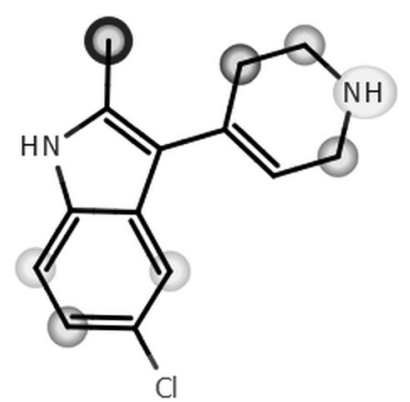

Fig. 3 The plot of MetaSite predictions for sites of metabolism of EMD386088

were used as references. EMD386088 did not influence CYP3A4 activity, and was determined as a very weak CYP2D6 inhibitor (EMD386088 $\left.I C_{50}=2.25 \mu \mathrm{M}\right)$ (Fig. 9). Thus, the effect of EMD386088 on CYPs 3A4/2D6 may be rather excluded as a potential reason responsible for the observed activity of EMD386088 co-administered with antidepressants.

\section{Discussion}

The major finding of the present study was that the inactive dose of a partial agonist of 5-HT 6 receptor EMD386088 coadministered with an inactive dose of some antidepressants (i.e., imipramine, moclobemide, reboxetine, and bupropion) induced pronounced anti-immobility effects in rats. Only during coadministration of inactive doses of EMD386088 and scitalopram antidepressant-like activity in FST has not been observed. Moreover, all the above-described positive interactions seem to be specific, since there was no increase in exploratory activity of rats after administration of the investigated compounds (single or combined).

The FST is the most extensively used behavioral procedure for detecting the potential antidepressant activity of compounds. The modified version of FST has been shown to reliably detect the antidepressant activity of selective serotonin reuptake inhibitors (SSRIs) as well as other compounds that produce their effects by activating the 5-HT system
Fig. 4 EMD386088 metabolites ranking generated by MetaSite software

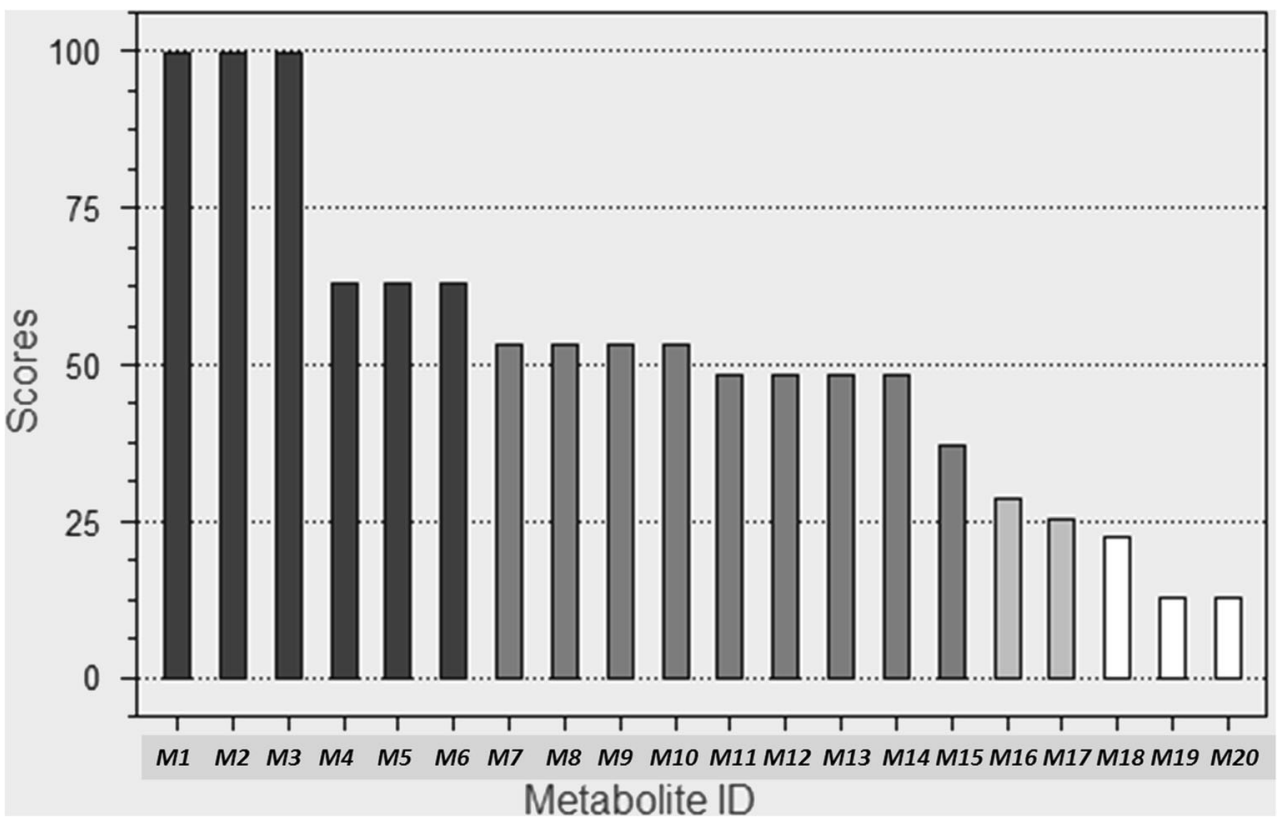


<smiles>O=Cc1[nH]c2ccc(Cl)cc2c1C1=CCNCC1</smiles>

$M 1$

$M W=260.07$<smiles>O=C(O)c1[nH]c2ccc(Cl)cc2c1C1=CCNCC1</smiles>

M2 $M W=276.07$<smiles>OCc1[nH]c2ccc(Cl)cc2c1C1=CCNCC1</smiles>

M3

$M W=262.09$<smiles>Cc1[nH]c2ccc(Cl)cc2c1C1=CCNCC1O</smiles>

M4

$M W=262.09$<smiles>Cc1[nH]c2ccc(Cl)cc2c1C1=CCNC=C1</smiles>

M5

$M W=244.08$<smiles>Cc1[nH]c2ccc(Cl)cc2c1C1=CCNCC1=O</smiles>

M6<smiles>Cc1[nH]c2ccc(Cl)cc2c1/C(=C/CN)CC=O</smiles>

M7<smiles>Cc1[nH]c2ccc(Cl)cc2c1/C(=C/CN)CC(=O)O</smiles>

M8<smiles>Cc1[nH]c2ccc(Cl)cc2c1C1=CCN=CC1</smiles>

M9

$M W=244.08$<smiles>Cc1[nH]c2ccc(Cl)cc2c1C1=CCNC(=O)C1</smiles>

M10

$M W=260.07$

Fig. 5 Structures of 10 most probably (scores $>50 \%$ ) metabolites of EMD386088 generated by MetaSite software

(Detke et al. 1995; Cryan et al. 2005). The modified FST showed that swimming behavior was increased by SSRIs, while climbing behavior was increased by antidepressants with a selective impact on catecholamine transmission (Detke et al. 1995; Cryan et al. 2005). The most potent antidepressant-like activity in FST was observed after

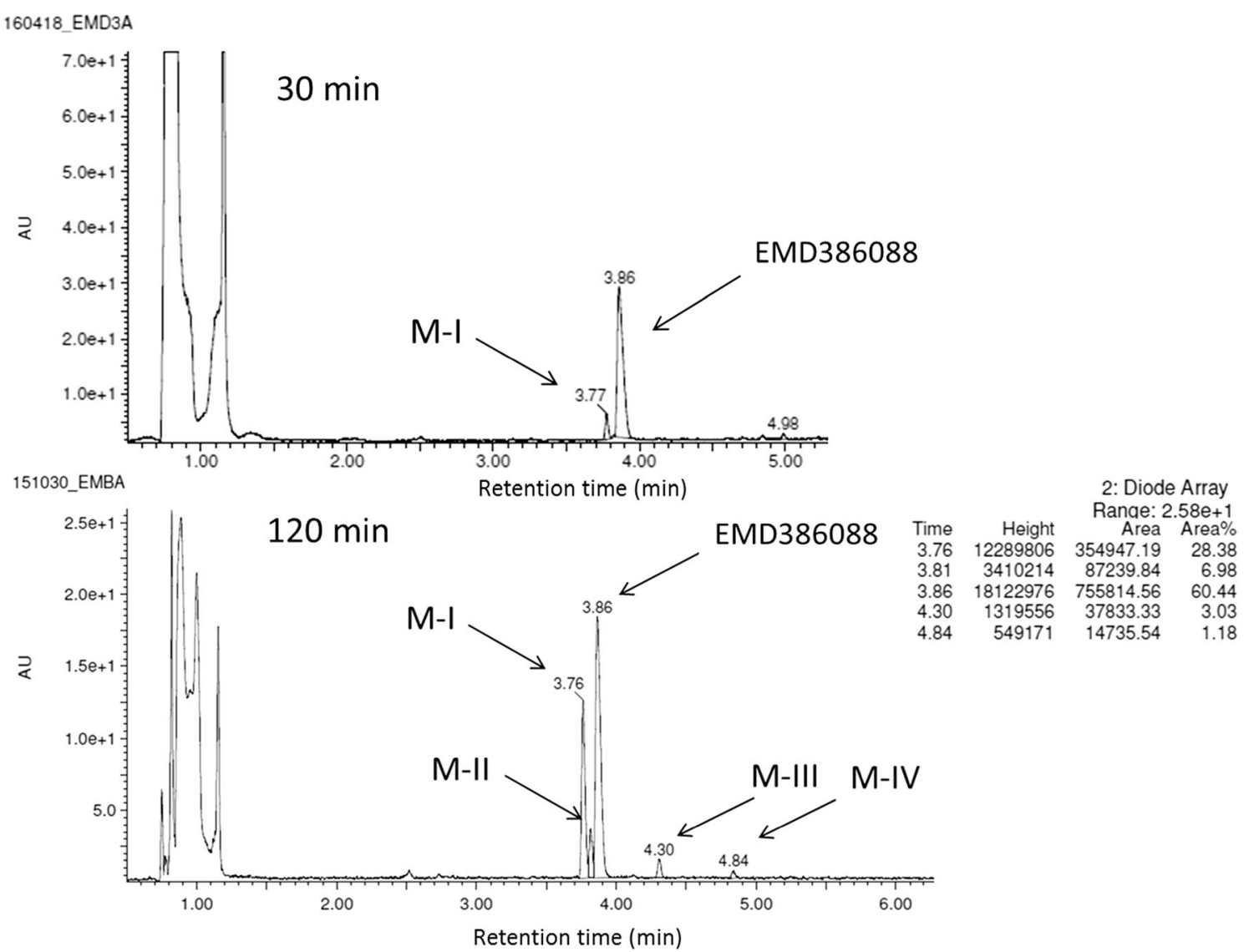

Fig. 6 The UPLC spectra after 30 and 120 min reaction of EMD386088 with RLMs. UPLC ultra-performance liquid chromatography, RLMs rat liver microsomes 


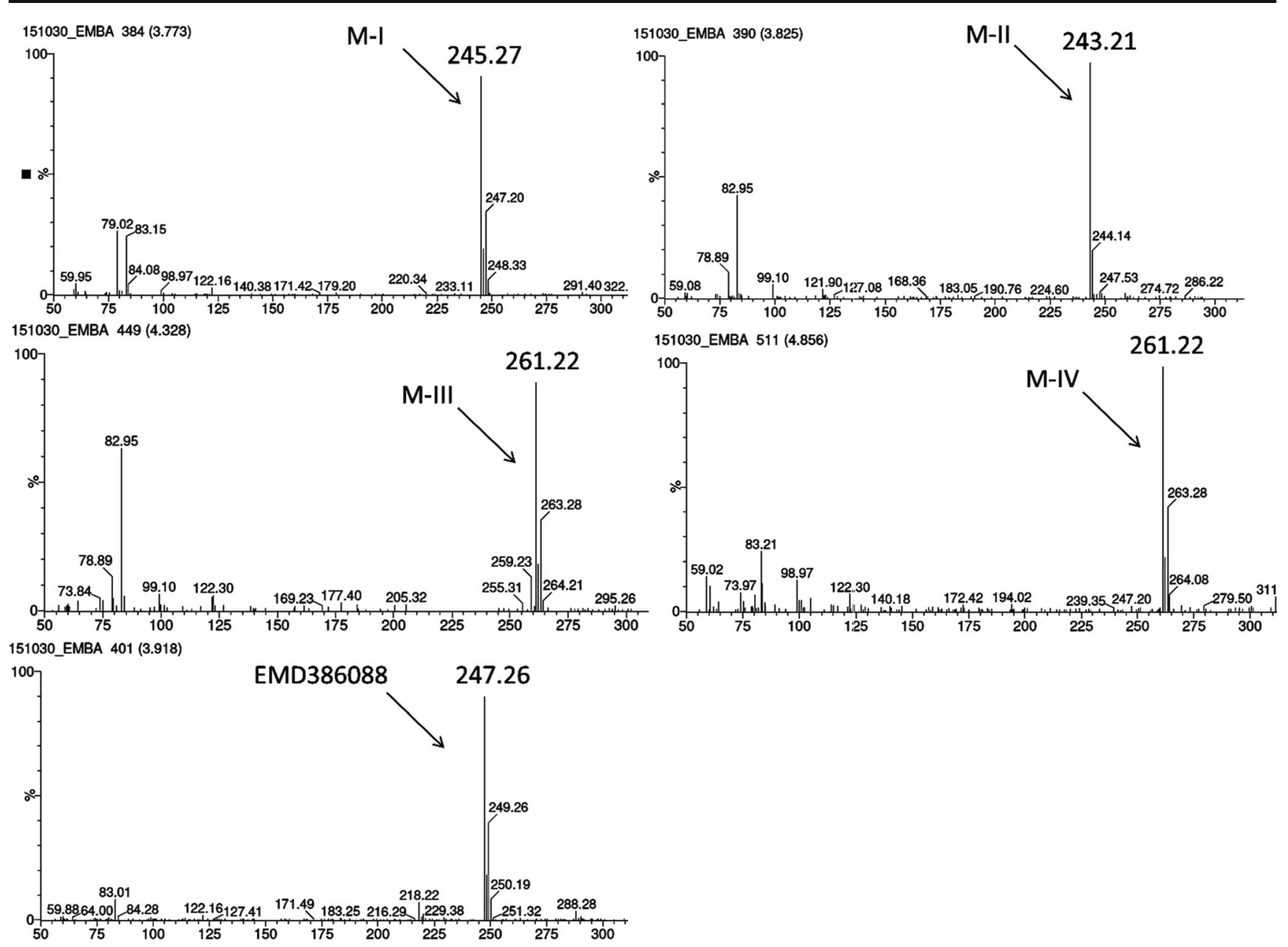

Fig. 7 MS spectra of EMD386088 and its metabolites in the total ion chromatogram after 120 min of incubation with RLMs. MS mass spectrometer, $R L M s$ rat liver microsomes

coadministration of non-active doses of EMD386088 and imipramine (a significant increase in the climbing behavior and a decrease in immobility, compared to single administration as well as to control group). Imipramine acts as a nonselective 5-HT and noradrenaline reuptake inhibitor (Schloss and Williams 1998; Slattery et al. 2004). Our previous study has revealed that EMD386088 did not show any significant effect on 5-HT and its intraneuronal metabolite (5hydroxyindoleacetic acid) concentrations in brain structures (striatum, nucleus accumbens, and hippocampus) of different

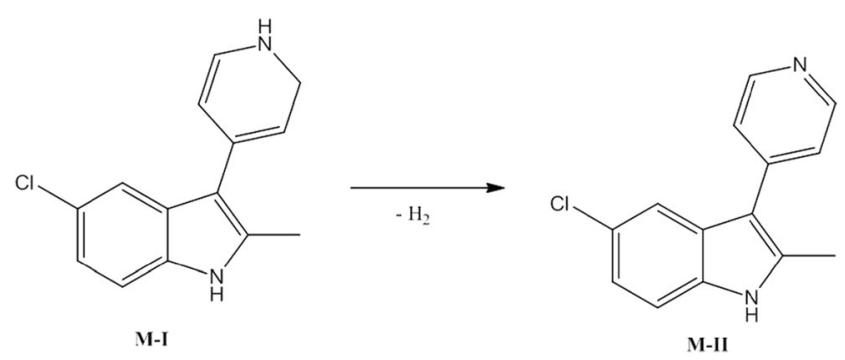

Fig. 8 Proposed structure of metabolite M-II of EMD386088 rats. Moreover, Ward et al. (1995) found a 5- $\mathrm{HT}_{6}$ receptor mRNA in 5-HT projection fields rather than in region containing cell bodies, which suggests post-synaptical localization of 5- $\mathrm{HT}_{6}$ receptors, and Gérard et al. (1996) reported that 5- $\mathrm{HT}_{6}$ receptors are located outside 5-HT neurons. Our results are in line with above-presented data. Activation of 5- $\mathrm{HT}_{6}$ receptors by EMD386088 does not promote the antidepressant-like activity of s-citalopram in rats.

Besides the serotonergic and noradrenergic neurotransmission, the dopaminergic pathways may also be involved in the pathomechanism of depression (Randrup and Braestrup 1977). This system is associated with serotonergic, GABAergic, cholinergic, and glutamatergic neurotransmission and interactions between them contribute to changes in their mutual signaling. Our previous neurochemical data from ex vivo experiments as well as behavioral data showed that anti-immobility activity of EMD386088 may be connected with the activation of dopaminergic system, while neither noradrenergic nor serotonergic systems are involved in its effect. EMD386088 also possesses a significant affinity for dopamine 
Fig. 9 Effects of EMD386088 on recombinant human CYP3A4 and 2D6 P450 cytochromes activity
CYP3A4

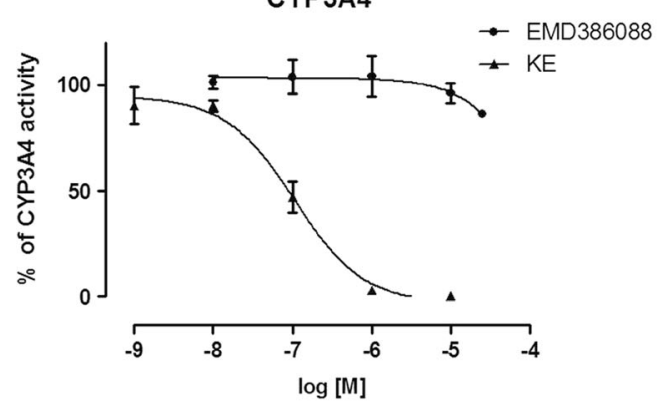

CYP2D6

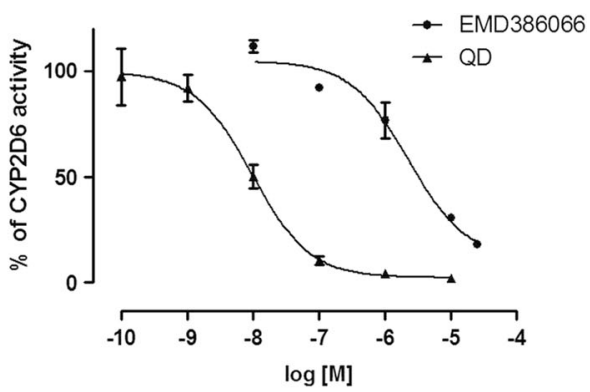

transporter, which may be the mechanism responsible for the abovementioned effect (Jastrzębska-Więsek et al. 2016). Thus, the most effective activity observed for coadministration of the $5-\mathrm{HT}_{6}$ receptor partial agonist and imipramine depends on the involvement of three neurotransmitter systems, i.e., dopaminergic from EMD386088 side and serotonergic and noradrenergic from imipramine side unless pharmacokinetic interaction plays an important role here.

Pharmacokinetic drug-drug interaction occurs when one drug changes the concentration of another by affecting its absorption, distribution, metabolism, or excretion (Corrie and Hardman 2014). To the best of our knowledge, there are no literature data about pharmacokinetic properties of EMD386088. Therefore, to evaluate the physical properties of EMD386088 and its interaction with imipramine, some pharmacokinetic parameters as well as brain and serum concentrations of both compounds, administered i.p. to rats, were determined. The pharmacokinetic study in vivo has revealed a rapid absorption of EMD386088 and a large volume of distribution, which indicates its penetration into the peripheral compartments after i.p. administration. Furthermore, EMD386088 administered individually penetrates the blood-brain barrier with a high brain/plasma ratio. These data are in line with the present and our previous findings. A dose of $2.5 \mathrm{mg} / \mathrm{kg}$ is not active in the FST and produced a lower brain concentration in the brain of rat. Our earlier data indicated that EMD 386088 at a dose of $5 \mathrm{mg} / \mathrm{kg}$ i.p. exerts an antidepressant-like effect in the FST in rats (JastrzębskaWięsek et al. 2015). This has been confirmed by at least a double increase in the concentration of EMD386088 in brain. Coadministration of EMD386088 and imipramine resulted in a slower absorption of the compound, decrease in the volume of distribution, and decrease in penetration by 2.5 fold.

Most of the isoenzymes of cytochrome P450 are involved in the metabolism of antidepressant drugs, especially CYP3A4 and CYP2D6 (Spina et al. 2008). Hence, if changes in the brain concentration of an antidepressant are observed after coadministration with another drug, there might be an inhibition of enzymes involved in the biotransformation. But, the in silico and in vitro studies on the metabolic stability of EMD386088 showed the dehydrogenation of tetrahydropyridine moiety as its main metabolic pathway. Furthermore, EMD386088 did not influence on CYP3A4 activity, and has been classified as a very weak CYP2D6 inhibitor. Moreover, no increase in brain concentration of imipramine+EMD386088 was noted. The increase in antidepressant-like activity of these drugs was most likely related to another possibility. EMD386088 was characterized with a very high permeability for the brain. It is well documented that amphiphilic or basic $(\mathrm{pKa}>8)$ lipophilic drugs are extensively metabolized and can be taken up by acidic compartments like lysosomes. Lysosomes constitute the largest and the most important acidic cell compartment $(\mathrm{pH}=4-5)$ and play a significant role in pharmacokinetics. Weak bases in nonionized state diffuse through biological membranes and accumulate in the acidic interior of lysosomes, where they are protonated and become unable to diffuse back into cytosol, which leads to the accumulation of a drug (Walczak 2013). Lysosomes are present in lungs, liver, kidneys, spleen, leukocytes, and macrophages and in smaller quantities in the brain, heart, muscles, and adipose tissue. The process of lysosomal trapping is saturable, energy-dependent, and requires cellular integrity. In the present study, coadministration of EMD386088 with imipramine decreases the compound permeability to brain. Imipramine is known as an inhibitor of lysosomal trapping (Daniel and Wojcikowski 1999). A substantial decrease of EMD386088 concentration in lysosomes (depot form) observed in vivo leads to an increase in its plasma concentration which, in turn, decreases the compound's volume of distribution.

\section{Conclusions}

In summary, the activation of 5- $\mathrm{HT}_{6}$ receptor may facilitate antidepressant-like activity of some antidepressants, whose mechanism of action is connected with 
dopaminergic and noradrenergic transmission. The effect of EMD386088 on CYP3A4 and CYP2D6 may be rather excluded as a potential reason responsible for the observed interactions. The distribution kinetics of EMD386088 is driven by the compound lipophilicity and uptake into lysosomes, and these phenomena provide a possible basis for the compound interaction with other drugs, e.g., antidepressants in preclinical studies.

Funding information This work was financially supported by Adamed Ltd., NCBiR, Warsaw, Poland (project no. KB/88/12655/ITT1-C/U/08) and founds for Statutory Activity of Jagiellonian University Medical College, Cracow, Poland (K/ZDS/006133 and partially by K/ZDS/ 006223).

\section{Compliance with ethical standards}

Conflict of interest The authors declare that they have no conflict of interest. Marcin Kołaczkowski is an employee of Adamed Ltd.

Open Access This article is distributed under the terms of the Creative Commons Attribution 4.0 International License (http:// creativecommons.org/licenses/by/4.0/), which permits unrestricted use, distribution, and reproduction in any medium, provided you give appropriate credit to the original author(s) and the source, provide a link to the Creative Commons license, and indicate if changes were made.

\section{References}

Cali JJ, Ma D, Sobol M et al (2006) Luminogenic cytochrome P450 assays. Expert Opin Drug Metab Toxicol 2:629-645. https://doi. org/10.1517/17425255.2.4.629

Carr GV, Schechter LE, Lucki I (2011) Antidepressant and anxiolytic effects of selective 5-HT6 receptor agonists in rats. Psychopharmacology 213:499-507. https://doi.org/10.1007/ s00213-010-1798-7

Corrie K, Hardman JG (2014) Mechanisms of drug interactions: pharmacodynamics and pharmacokinetics. Anaesth Intensive Care Med 15: 305-308. https://doi.org/10.1016/j.mpaic.2014.04.005

Cruciani G, Carosati E, De Boeck B et al (2005) MetaSite: understanding metabolism in human cytochromes from the perspective of the chemist. J Med Chem 48:6970-6979. https://doi.org/10.1021/ jm050529c

Cryan JF, Valentino RJ, Lucki I (2005) Assessing substrates underlying the behavioral effects of antidepressants using the modified rat forced swimming test. Neurosci Biobehav Rev 29:547-569. https://doi.org/10.1016/j.neubiorev.2005.03.008

Daniel A, Wojcikowski J (1999) Lysosomal trapping as an important mechanism involved in the cellular distribution of perazine and in pharmacokinetic interaction with antidepressants. Eur Neuropsychopharmacol 9:483-491

Detke MJ, Rickels M, Lucki I (1995) Active behaviors in the rat forced swimming test differentially produced by serotonergic and noradrenergic antidepressants. Psychopharmacology 121:66-72

Gérard C, el Mestikawy S, Lebrand C et al (1996) Quantitative RTPCR distribution of serotonin 5-HT6 receptor mRNA in the central nervous system of control or 5,7-dihydroxytryptaminetreated rats. Synapse 23:164-173. https://doi.org/10.1002/ (SICI)1098-2396(199607)23:3\&lt;164::AID-SYN5\&gt;3.0.CO; 2-6
Hirano K, Piers TM, Searle KL et al (2009) Procognitive 5-HT6 antagonists in the rat forced swimming test: potential therapeutic utility in mood disorders associated with Alzheimer's disease. Life Sci 84: 558-562. https://doi.org/10.1016/j.lfs.2009.01.019

Jastrzębska-Więsek M, Siwek A, Kazek G et al (2013) Partial agonist efficacy of EMD386088, a 5-HT6 receptor ligand, in functional in vitro assays. Pharmacol Reports 65:998-1005

Jastrzębska-Więsek M, Siwek A, Partyka A et al (2014) Pharmacological evaluation of the anxiolytic-like effects of EMD 386088, a partial 5HT6 receptor agonist, in the rat elevated plus-maze and Vogel conflict tests. Neuropharmacology 85C:253-262. https://doi.org/10. 1016/j.neuropharm.2014.05.036

Jastrzębska-Więsek M, Siwek A, Partyka A et al (2015) Antidepressantlike activity of EMD 386088, a 5-HT6 receptor partial agonist, following systemic acute and chronic administration to rats. Naunyn Schmiedeberg's Arch Pharmacol:2-11. https://doi.org/10.1007/ s00210-015-1141-2

Jastrzębska-Więsek M, Siwek A, Partyka A et al (2016) Study of a mechanism responsible for potential antidepressant activity of EMD 386088, a 5-HT6 partial agonist in rats. Naunyn Schmiedeberg's Arch Pharmacol. https://doi.org/10.1007/s00210-016-1245-3

Mattsson C, Sonesson C, Sandahl A et al (2005) 2-Alkyl-3-(1,2,3,6tetrahydropyridin-4-yl)-1H-indoles as novel 5-HT6 receptor agonists. Bioorg Med Chem Lett 15:4230-4234. https://doi.org/10. 1016/j.bmcl.2005.06.067

Monsma FJ, Shen Y, Ward RP et al (1993) Cloning and expression of a novel serotonin receptor with high affinity for tricyclic psychotropic drugs. Mol Pharmacol 43:320-327

Nikiforuk A, Kos T, Wesołowska A (2011) The 5-HT6 receptor agonist EMD 386088 produces antidepressant and anxiolytic effects in rats after intrahippocampal administration. Psychopharmacology 217: 411-418. https://doi.org/10.1007/s00213-011-2297-1

Plassat JL, Amlaiky N, Hen R (1993) Molecular cloning of a mammalian serotonin receptor that activates adenylate cyclase. Mol Pharmacol 44:229-236

Porsolt RD, Bertin A, Jalfre M (1978) "Behavioural despair" in rats and mice: strain differences and the effects of imipramine. Eur J Pharmacol 51:291-294

Randrup A, Braestrup C (1977) Uptake inhibition of biogenic amines by newer antidepressant drugs: relevance to the dopamine hypothesis of depression. Psychopharmacology 53:309-314

Ruat M, Traiffort E, Arrang JM et al (1993) A novel rat serotonin (5-HT6) receptor: molecular cloning, localization and stimulation of cAMP accumulation. Biochem Biophys Res Commun 193:268-276

Sadek B, Saad A, Latacz G et al (2016) Non-imidazole-based histamine $\mathrm{H} 3$ receptor antagonists with anticonvulsant activity in different seizure models in male adult rats. Drug Des Devel Ther 10:3879-3898. https://doi.org/10.2147/DDDT.S116192

Schloss P, Williams DC (1998) The serotonin transporter: a primary target for antidepressant drugs. J Psychopharmacol 12:115-121. https:// doi.org/10.1177/026988119801200201

Slattery DA, Hudson AL, Nutt DJ (2004) Invited review: the evolution of antidepressant mechanisms. Fundam Clin Pharmacol 18:1-21. https://doi.org/10.1111/j.1472-8206.2004.00195.x

Spina E, Santoro V, D’Arrigo C (2008) Clinically relevant pharmacokinetic drug interactions with second-generation antidepressants: an update. Clin Ther 30:1206-1227. https://doi.org/10.1016/S01492918(08)80047-1

Svenningsson P, Tzavara ET, Qi H et al (2007) Biochemical and behavioral evidence for antidepressant-like effects of 5-HT6 receptor stimulation. J Neurosci 27:4201-4209. https://doi.org/10.1523/ JNEUROSCI.3110-06.2007

Takamori K, Yoshida S, Okuyama S (2001) Repeated treatment with imipramine, fluvoxamine and tranylcypromine decreases the number of escape failures by activating dopaminergic systems in a rat learned helplessness test. Life Sci 69:1919-1926 
Walczak M (2013) Binding of new aminopropan-2-ol compounds to bovine serum albumin, $\alpha 1$-acid glycoprotein and rat serum using equilibrium dialysis and LC/MS/MS. Pharmacol Rep 65:12941303

Ward RP, Hamblin MW, Lachowicz JE et al (1995) Localization of serotonin subtype 6 receptor messenger RNA in the rat brain by in situ hybridization histochemistry. Neuroscience 64:1105-1111. https:// doi.org/10.1016/0306-4522(94)00439-C

Wesolowska A (2008) The anxiolytic-like effect of the selective 5-HT6 receptor antagonist SB-399885: the impact of benzodiazepine receptors. Eur J Pharmacol 580:355-360. https://doi.org/10.1016/j.ejphar. 2007.11.022
Wesołowska A, Nikiforuk A (2007) Effects of the brain-penetrant and selective 5-HT6 receptor antagonist SB-399885 in animal models of anxiety and depression. Neuropharmacology 52:1274-1283. https:// doi.org/10.1016/j.neuropharm.2007.01.007

Wesołowska A, Nikiforuk A, Stachowicz K (2007) Anxiolytic-like and antidepressant-like effects produced by the selective 5-HT6 receptor antagonist SB-258585 after intrahippocampal administration to rats. Behav Pharmacol 18:439-446. https://doi.org/10.1097/FBP. 0b013e3282d28f9c

Yoshioka M, Matsumoto M, Togashi H et al (1998) Central distribution and function of 5-HT6 receptor subtype in the rat brain. Life Sci 62: 1473-1477. https://doi.org/10.1016/S0024-3205(98)00092-7 